\title{
ОБ ИСТОЧНИКАХ УГЛЕРОДА И ТЕМПЕРАТУРАХ КРИСТАЛЛИЗАЦИИ ГРАФИТА В ПОРОДАХ КЕЙВСКОГО БЛОКА. НОВЫЕ ДАННЫЕ
}

\author{
Фомина Е.Н. ${ }^{1}$, Лохова О.А. ${ }^{2}$, Бочаров В.Н. ${ }^{3}$ \\ ${ }^{1}$ Геологический институт КНЦ РАН, Anamumbl,fomina_e.n@mail.ru \\ ${ }^{2}$ Институт истории материальной культуры РАН, Санкт-Петербург \\ ${ }^{3}$ Ресурсный Центр «Геомодель», СПбГУ, Санкт-Петербург
}

В определениях возрастов, стратиграфического положения, а также оценках метаморфометасоматических преобразований супракрустальных толщ Кейвского блока до сих пор существует ряд дискуссионных проблем, затрудняющих интерпретацию его геологического развития. Так, на основании парагенетического анализа и геохимической термобарометрии предшественниками [4] было установлено, что метаосадочные образования кейвского подкомплекса регионально метаморфизованы в условиях кианит-ставролит-двуслюдяной субфации амфиболитовой фации в температурном диапазоне $550-600^{\circ} \mathrm{C}$. При этом отмечается, что на Западных Кейвах под воздействием щелочных гранитов кианитовые парагенезисы сменяются силлиманитовыми, образующимися при температуре $620^{\circ} \mathrm{C}$ [7], а в Малокейвской структурной зоне степень метаморфизма снижается в направлении к ЮВ до эпидот - амфиболитовой фации $\left(<500^{\circ} \mathrm{C}\right)$ [4]. Однако привязки метаморфических событий к геодинамическим этапам развития Кейвского блока, равно как установление термодинамических характеристик и, следовательно, метаморфической зональности во многих аспектах остаются неточными, а иногда и противоречивыми. В связи с этим для выяснения источников вещества и эволюции супракрустальных толщ Кейв требуются дополнительные маркеры.

Одним из наиболее надежных маркеров может служить графит, который присутствует практически во всех породах кейвского комплекса [5]. Поскольку отношения ${ }^{13} \mathrm{C} /{ }^{12} \mathrm{C}$ основных резервуаров углерода контрастны, изотопные характеристики углерода графита широко используются для выяснения источников углерода. Кроме того, весьма информативной является степень упорядоченности углеродистого вещества, способная весьма чутко отражать условия его кристаллизации, оставаясь весьма стабильной в ходе дальнейших преобразований. На основании этого свойства для разных типов пород было разработано несколько рамановских графитовых геотермометров [8], [9] и др., широко применяемых для оценок пиковых температур контактового, регионального метаморфизма и метасоматоза.

В кейвских метаморфизованных толщах еще в 1970-е годы было отмечено наличие изотопно легкого углерода (-35 \% $\delta 13 \mathrm{C}$ PDB) [5]. Позднее еще более «аномально легкие» значения $(-42 \ldots-48 \%$ \% $\delta 13 \mathrm{C} \mathrm{PDB})$ были получены для метасоматитов из зон деформаций [2]. Нами на основании изучения графита в кианитовых, силлиманитовых сланцах и силекситах из щелочных гранитов было показано [6], что поступление углерода в породы на изучаемой территории происходило по меньшей мере из двух источников: (1) водно-метанового флюида из осадочных пород с органическими соединениями ( $\delta 13 \mathrm{C}$ РDB до $-45 \%$ ) и (2) углекислотного флюида, поступавшего непосредственно из щелочных гранитов ( $\delta 13 \mathrm{C}$ PDB в среднем $-8 \%$ ). Однако для уточнения полученных результатов и их сопоставления с геологическими данными требовалось накопление большего объема аналитических данных как по исследовавшимся ранее, так и по новым объектам.

Стремясь наиболее полно охарактеризовать графитоносные породы Кейвского блока, в качестве материала мы исследовали вещество из максимально территориально разобщенных объектов. Изучению подверглись графитсодержащих силекситов из щелочных гранитов Западных Кейв, а также породы червуртской свиты кейвской серии: образцы кианитовых сланцев г. Тяпшманюк и г. Шуурурта Центральных Кейв; силлиманитовых и слюдяных сланцев г. Макзабак Западных Кейв; кианитовых сланцев из участка оз. Романово на ЮВ Малых Кейв (рис. 1а).

Для выяснения отношения ${ }^{13} \mathrm{C} /{ }^{12} \mathrm{C}$ в графите изучаемых пород мы провели изотопные исследования углерода в ИИМК РАН на масс-спектрометре IRMC DELTA V (ThermoFinnigan). Регистрация рамановских спектров (РС) для изучения структурных характеристик углеродистого вещества производилась в ИГ КарНЦ РАН при помощи дисперсионного спектрометра комбинационного рас- 
сеяния Nicolet Almega XP (Thermo Scientific), а также в РЦ «Геомодель» научного парка СПбГУ при помощи спектрометра HORIBA Jobin-Yvon LabRam HR800. Описания пробоподготовки, экспериментальных исследований, разложения РС и расчета температур подробно даны в работе [6].

На основании петрографо-минераграфического изучения вышеупомянутой коллекции образцов было установлено пять генераций графита. Графит первой генерации (Gr-1) в виде тонкодисперсных включений в породообразующих минералах, а также интерстиционный мелкочешуйчатый Gr-2 в переменных количествах присутствуют почти во всех изученных породах червуртской свиты, достигая максимальных содержаний в кианитовых сланцах (в среднем 2.3 мас. \%). В образцах кианитовых сланцев г. Тяпшманюк изотопный состав углерода этих образований оказался идентичным и довольно гомогенным: $\delta^{13} \mathrm{C}$ (PDB) от -43.4 до $-44.8 \%$ (по 8 анализам). Структурно они несколько отличаются, что отразилось в анализе рамановских спектров. Рассчитанные по ним температурные диапазоны образования этих модификаций оказались весьма различными: для Gr-1 получены значения $470-530^{\circ} \mathrm{C}$, а для Gr-2 $-565-570^{\circ} \mathrm{C}$ (рис. 1 б). В сланцах участка оз. Романово
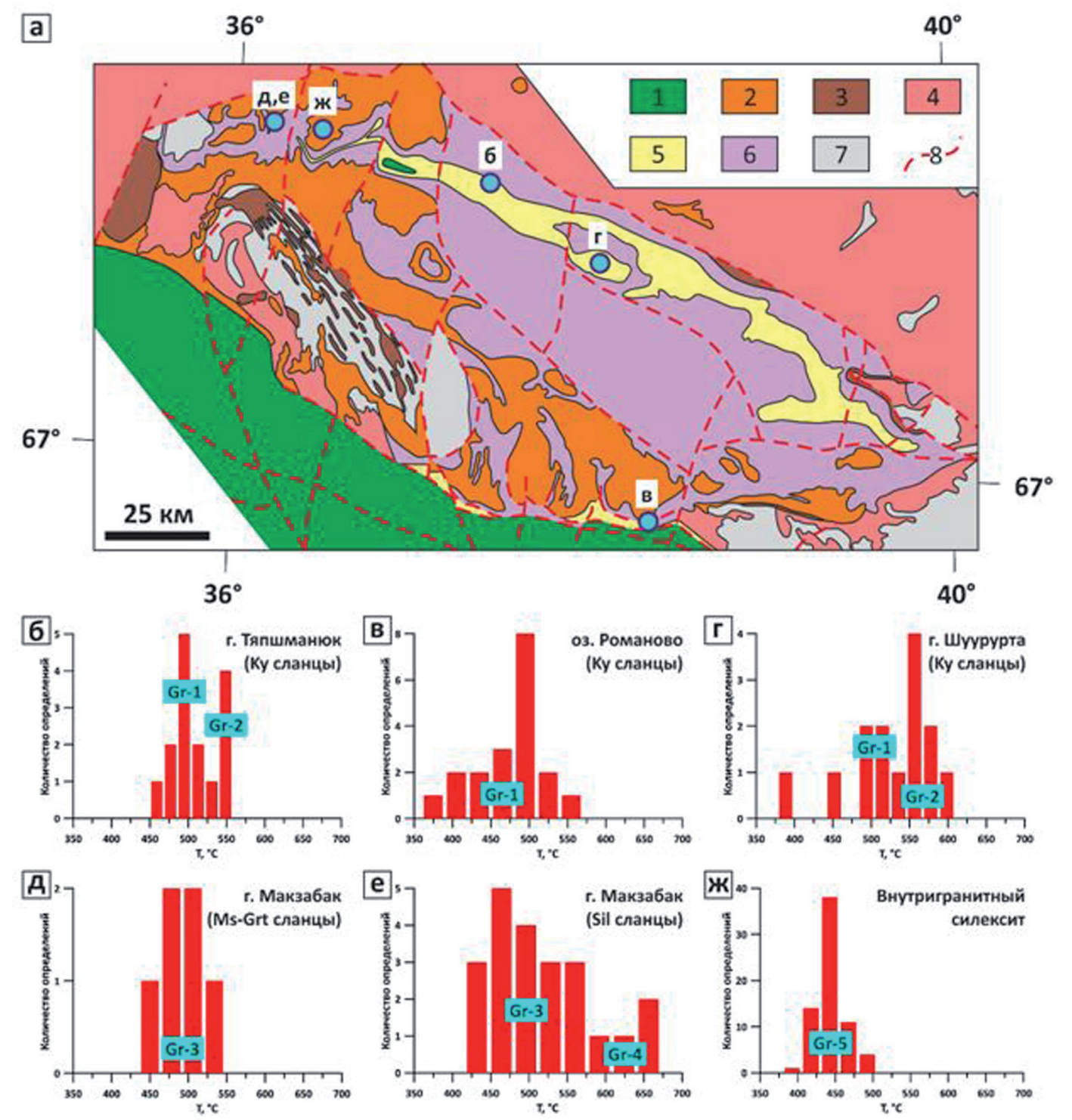

Рис. 1. (а) Схема отбора проб. Геологическая основа по [3] с упрощениями.

1 - базиты и ультрабазиты, $\mathrm{PR}_{1} ; 2$ - щелочные граниты, $\mathrm{AR}_{2} ; 3$ - габброиды, $\mathrm{AR}_{2} ; 4$ - гранитоиды нормальной щелочности (нерасчлененные), $\mathrm{AR}_{2} ; 5$ - глиноземистые сланцы кейвской серии, $\mathrm{AR}_{2} ; 6$ - породы тундровой серии (слюдяные парасланцы), $\mathrm{AR}_{2} ; 7$ - гнейсы и амфиболиты кольской серии (комплекса основания), AR; 8 - тектонические нарушения; (б)-(г) Гистограммы температур графита, определенных с помощью рамановского геотермометра [7]. Аббревиатуры соответствуют приведенным в тексте. 
был обнаружен лишь тонкодисперсный Gr-1. По изотопному составу он близок к таковому г. Тяпшманюк (от -41.3 до $-46.8 \%$, по 12 анализам), но диапазон температур для него оказался более широким: от 400 до $520^{\circ} \mathrm{C}$ при медиане $480^{\circ} \mathrm{C}$ (рис. 1 в). Кианитовые сланцы г. Шуурурта также насыщены и $\mathrm{Gr} 1$, и Gr-2. Температуры их образования подобны рассчитанным для графитов г. Тяпшманюк $\left(450-520^{\circ} \mathrm{C}\right.$ и $560-600^{\circ} \mathrm{C}$ соответственно, рис. 1 г). Однако изотопные данные по углероду для этих пород разделились на два интервала. Пять анализов дали значение $\delta^{13} \mathrm{C}(\mathrm{PDB})-41.3$ и $-45.1 \%$, то есть аналогичные вышеуказанным. В остальных же 12 оно варьирует в пределах от -27.3 до -38.3 \%о при медиане $-33.0 \%$, что сопоставимо с результатами, полученными в работе [4].

Графит Gr-3 присутствует в виде крупных чешуек в межзерновом пространстве слюдяногранатовых сланцев и образует сегрегации этих чешуй (желваки, гнезда размером до 10 см) в силлиманитовых сланцах г. Макзабак. Диапазон вариаций $\delta^{13} \mathrm{C}(\mathrm{PDB})$ для 22 проб Gr-3 из силлиманитовых сланцев составил $-16.8 \ldots-19.8 \%$. Результатов изотопных анализов по слюдяно-гранатовым сланцам в связи с малым содержанием в пробах графита получено не было. Однако об идентичности крупночешуйчатого графита из них гнездовому из силлиманитовых пород помимо морфологии и микроструктурных характеристик говорит и одинаковый интервал температур образования - от 435 до $520^{\circ} \mathrm{C}$ (медиана $\left.500^{\circ} \mathrm{C}\right)$ (рис. 1 д).

Gr-4 был обнаружен только в силлиманитовых сланцах, где он формирует прожилки (мощностью от первых мм до 2 см), сложенные смесью крупных изогнутых лейст графита, зерен монацита, рутила и ильменита, рассекающие гнезда Gr-4 и практически все породообразующие фазы. По структурному положению и взаимоотношениям с прочими минералами мы предположили, что эта генерация графита является наиболее поздней в силлиманитовых сланцах и может быть связана с флюидной переработкой пород, сопутствовавшей становлению щелочно-гранитных массивов. Предположение это подтверждается и геохимией, и спектроскопией. Углерод Gr-4 оказался существенно более «тяжелым»: $\delta^{13} \mathrm{C}(\mathrm{PDB})=-10.1 \% \ldots-10.7 \%$. Структура его значительно более упорядочена, а оценка температур составляет $570-670^{\circ} \mathrm{C}$ при медиане $615^{\circ} \mathrm{C}$ (рис. 1 е).

Для оценки изотопных и структурных характеристик углеродистого вещества непосредственно из щелочных гранитов были изучены графитовые сферолиты (Gr-5) из внутригранитных силекситов. Они содержат наиболее изотопно “тяжелый” углерод из всех проанализированных проб: $\delta 13 \mathrm{C}(\mathrm{PDB})=-5.6 \ldots-8.5 \%$ (по 8 анализам). Диапазон температур для $\mathrm{Gr}-5$ составил $435-480^{\circ} \mathrm{C}$ при медиане $445^{\circ} \mathrm{C}$ (рис. 1 ж).

Установленные изотопно-геохимические характеристики и структурные особенности пяти выделенных типов графита позволяют сделать следующие заключения.

1. Источник «аномально легкого» углеродистого вещества (Gr-1 и Gr-2) существовал на весьма обширной территории - от северо-запада Больших Кейв до юго-востока Малых. При этом поставщиком углерода, обогащенного изотопом ${ }^{13} \mathrm{C}$, предположительно был водно-метановый флюид из осадочных пород с органическими соединениями. «Тяжелый» углерод в силекситах и силлиманитовых сланцах (Gr-5 и Gr-4), по всей видимости, фиксировался из водно-углекислотных нижнекоровых или мантийных флюидов при становлении гранитов. Гнездовой графит из силлиманитовых сланцев (Gr-3), вероятно, представляет собой продукт смешения этих двух источников. Наличие помимо «аномально легкого» углерода в кианитовых сланцах г. Шуурурта изотопной метки со значением близким $-33.0 \% \delta^{13} \mathrm{C}(\mathrm{PDB})$ указывает на вероятность существования третьего, дополнительного углеродного резервуара, более обедненного изотопом ${ }^{13} \mathrm{C}$, коим могло являться биогенное вещество, возможность существования которого в этих породах обсуждалась в работе [1].

2. Обнаружение на ЮВ Малых Кейв лишь низкотемпературной модификации графита согласуется с петрологическими обоснованиями возможности снижения степени метаморфизма в этом районе до эпидот-амфиболитовой фации в работе [4]. Мы предполагаем две версии о причине отсутствия более высокотемпературного графита и минеральных парагенезисов более высоких ступеней метаморфизма. Возможно эти породы не были вовлечены в некий поздний высокотемпературный этап преобразования пород, затронувший стратиграфически идентичные толщи в других районах. Либо в ходе некоторых метаморфических событий в районе Малых Кейв эти породы испыта- 
ли меньший прогрев, чем на Больших Кейвах. Для проверки этих версий требуются дополнительные данные.

3. Рассчитанные по рамановским геотермометрам диапазоны температур для каждого выделенного в ходе микроскопического описания морфологического типа графита довольно четко совпадают в разных образцах из различных участков. Структурные характеристики хорошо раскристаллизованного графита остаются устойчивыми даже при инфильтрации более поздних горячих флюидов, на что указывает неизменность структуры гнездового Gr-3 в местах его пересечения прожилками высокотемпературного Gr-4. Эти факты подтверждают высокую степень надежности графитового геотермометра в применении и к метаморфическим, и к метасоматическим образованиям.

Работа выполнена в ГИ КНЦ РАН по государственному заказу № 0231-2015-0007 при поддержке РФФИ (проект № 18-35-00068). Регистрация рамановских спектров производилась в РЦ «Геомодель» научного парка СПбГУ.

\section{Литература}

1. Астафьева М.М., Балаганский В.В. Кейвские парасланцы (архей-ранний протерозой), нанобактерии и жизнь // Стратиграфия. Геологическая корреляция. 2018. Т. 26. № 3. С. 1-11.

2. Бушмин С.А., Глебовицкий В.А., Прасолов Э.М., Лохов К.И., Вапник Е.А., Савва Е.В., Щеглова Т.П. Происхождение и состав флюида ответственного за метасоматические процессы в зонах сдвиговых деформаций тектонического покрова Большое Кейвы Балтийского щита: изотопный состав углерода графитов // ДАН. 2011. Т. 438. №3. С. 379-383.

3. Геологическая карта Кольского региона (северо-восточная часть Балтийского щита). Масштаб 1:500 000 / гл. ред. Ф.П. Митрофанов. Апатиты : ГИ КНЦ РАН. 1996.

4. Метаморфизм супракрустальных комплексов раннего докембрия / Петров В.П. и др. Л.: Наука. 1986. $272 \mathrm{c}$.

5. Сидоренко Св.А., Сидоренко А.В. Органическое вещество в осадочно-метаморфических породах докембрия // Тр. ГИН АН СССР. М.: Наука. 1975. 115 с.

6. Фомина Е.Н., Козлов Е.Н., Лохова О.В., Лохов К.И. Графит как индикатор контактового воздействия Западно-Кейвской интрузии щелочных гранитов, Кольский полуостров // Вестник МГТУ. 2017. Т. 20. № 1/1. С. 129-139.

7. Эндогенные режимы метаморфизма раннего докембрия (северо-восточная часть Балтийского щита) / Петров В.П. и др. Л.: Наука. 1990. 184 с.

8. Aoya M., Kouketsu Y., Endo S., Shimizu H., Mizukami T., Nakamura D., Wallis S. Extending the applicability of Raman carbonaceous-material geothermometer using data from contact metamorphic rocks // Journal of Metamorphic Geology. 2010. V. 28. №9. P. 895-914.

9. Beyssac O., Goffé B., Chopin C., Rouzaud J.N. Raman spectra of carbonaceous material in metasediments: a new geothermometer // Journal of Metamorphic Geology. 2002. V. 20. №9. P. 859-871. 